\title{
Ancient Ephesus: Processions as Media of Religious and Secular Propaganda
}

The significance of religious rituals often reaches beyond their strict religious intentions. Specifically a procession, performed in front of the public, is a most effective instrument of disseminating a message to the crowds. Consequently, this ritual, as is well known, has often been used not only in religious but also in secular contexts; a procession under the cloak of religion can even become a politically useful medium to avoid popular disturbances on peaceful terms. ${ }^{1}$ This was the case in ancient Ephesus, where Roman power conflicted with Greek culture from the middle of the first century B.C. onwards; the discord is testified by the famous Salutaris foundation, dating from A.D. 104-108/9, and perpetuated in a long Greek inscription, which has been known for more than a century (Rogers 1991: 19). Although this bequest on behalf of the temple of Artemis Ephesia and the city of Ephesus is one of the most important documents of its kind, the content and purpose has up to now received little attention among scholars; Vibius Salutaris' generosity, made visible in a magnificent procession (reflected even in the Ephesian church), has been explained only in passing as a manifestation of vanity (Cf. Nilsson, 1916: 317, Rogers 1991: 21). A monograph dealing with the Salutaris inscription has recently been published by G. M. Rogers (1991) presenting the procession, created by Vibius Salutaris, from a religious point of view in the context of the mysteries of Artemis Ephesia. Rogers relates the message of the procession to the buildings and works of art it passed on its way through the city; the procession in its physical context is interpreted as a symbolic statement of the Ephesian People mediating to the participating Ephesian young men in military service the sacred identity of the city based on the tradition that Artemis was born in

\footnotetext{
1 A survey of all processions in the Graeco-Roman world is given by Bömer 1952 .
} 
Ephesus (Rogers 1991: 136-151). In my opinion the Salutaris bequest is rather to be seen as a document of political propaganda, created by a Roman aristocrat according to the political program of the Emperor Trajan (A.D. 98-117), and testifying to the growing Romanisation of the city of Ephesus. ${ }^{2}$ Since my theory is anchored on the historical background of the city, I give the following brief outline on the subject.

Ephesus was originally colonized by the Athenians in about 1000 B.C.; later on, in the 4th century B.C., it was captured by the Thracian king Lysimachus who became of great importance to its further development. Consequently, the city was 'colonized' twice by the Greeks (Bürchner 1905: 2787-2798; Knibbe 1970: 251-269). In 133 B.C. Ephesus came into Roman supremacy when the Pergamene king Attalus III bequeathed Pergamon, also including the city of Ephesus, to Rome. As a consequence a great number of Italic business men invaded Ephesus since it was an important centre of trade situated between the East and the West (Knibbe 1970: 750-751). Because of the impoverishment of the city as a consequence of the abuse of the Roman tax collectors, Ephesus revolted against Rome in 88 B.C. in connection with Mithridates' effort to create a large Asian kingdom. In connection with this riot, named the 'Ephesian vesper', a great number of Ephesians of Italic origin were murdered, and the Roman revenge, effectuated by Sulla in 84 B.C., deprived the city of its prosperity for several decades. Nevertheless, the temple of Artemis Ephesia, who was the tutelary deity of the city (Oster 1990: 1700-1701), was for several reasons seen as a source of fear by the Romans; in this perspective it is worth noting that Mithridates gained favour with the Ephesians in extending the territory of its asylum (Knibbe and Alzinger 1980: 752-753). The temple was seen as an important power block in the Mediterreanean world, as is testified by the following descriptive accounts calling attention to various aspects of the cult. Pausanias, writing in the second half of the second century A.D., derives the rumour of the temple from its old age and magnificence:

But all cities worship Artemis of Ephesus, and individuals hold her in honour above all the gods. The reason, in my view, is the renown of the Amazons, who traditionally dedicated the image, also the extreme antiquity of this sanctuary. Three other points as well have contributed to her renown, the size of the temple, surpassing all buildings among men, the eminence of the city of the Ephesians and the renown of the goddess who dwells there. (Paus. IV, 31, 8. Transl. H. A. Ormerod)

\footnotetext{
${ }^{2}$ Although I have another approach to the Salutaris bequest, I am greatly indebted to the careful work done by G. M. Rogers.
} 
In an epigram dating from the beginning of the first century B.C., the poet Antipater from Sidon gives evidence to the temple of Artemis Ephesia as being one of the seven world wonders:

I have set eyes on the wall of lofty Babylon on which is a road for chariots, and the statue of Zeus by the Alpheus, and the hanging gardens, and the colossus of the Sun, and the huge labour of the high pyramids, and the vast tomb of Mausollos; but when I saw the house of Artemis that mounted to the clouds, these other marvels lost their brillancy, and I said, 'Lo, apart from the Olympus, the Sun never looked on aught so grand'. (Anth. Gr. IX, 58. Transl. W. R. Paton)

From Dio Chrysostom (A.D. c. 40-120) we get the information that its activity of banking (Oster 1990: 1719) was of the utmost importance to private as well as to public finances:

You know about the Ephesians, of course, and that large sums of money are in their hands, some of it belonging to private citizens and deposited in the temple of Artemis, not alone money of the Ephesians but also of aliens and of persons from all parts of the world, and in some cases of commonwealths and kings, money which all deposit there in order that it may be safe, since no one has ever dared to violate that place, although countless wars have occurred in the past and the city has been captured. (Dio Chr. orat. 31, 54. Transl. J. W. Cohoon-H. Lamar Crosby)

Finally, we know that the temple of Artemis Ephesia played an important role as an asylum, opening its gates to fugitives of all classes of society (Oster 1990: 1717). The hospitality of the temple towards slaves and political turncoats of all kinds in combination with its financial power, and its attractive force as a resort of pilgrims made it a dangerous centre of political unrest in the eyes of the Romans (Oster 1990: 1717-1719) Accordingly, the Emperor Augustus, introducing a period of intensified Romanisation of Ephesus on various levels (Knibbe 1981: 757-762; Knibbe and Alzinger 1980: 815-818), began a period of Roman infiltration in the temple of Artemis Ephesia. First of all, he so-to-say invited the goddess to the sacred heart of her city (Knibbe and Alzinger 1980: 817) in transplanting an important part of the male sacred hierachy from the temple, located outside the city wall, to the new-built town hall in the centre. (Knibbe and Alzinger 1980: 760-761). Secondly, he allowed the Ephesians to erect an Augusteum in the precinct of the temple, making himself the consort of the goddess (Knibbe 1981: 761); by these clever moves he managed to put the temple in control of Roman power - and furthermore, in a most flattering way. In my view the process of Romanising the cult of 
Artemis Ephesia, inaugurated by Augustus, was continued in the reign of Trajan by the bequest made by the Roman equestrian Vibius Salutaris on behalf of the city goddess. ${ }^{3}$ The long text (consisting of 568 lines) is divided into seven parts including, besides the main document (i.e. the deed of gift), the ratifications to the bequest given by the Council and the Popular Assembly and the representatives of the Roman government; in our perspective the main document (IEph 27, 11. 134-332) together with an additional paragraph of a later date (IEph 27, ll. 447-568) are of particular interest.

Focusing on the scope of the bequest, it included two different kinds of gifts. Firstly, it consisted of a large sum of money, the interest on which should be annually paid out to various groups of temple servants and members of the municipal government on the birthday of the goddess (Rogers 1991: 39-79). Secondly, it was made up of 31 metal statues to be lain before the public in a procession; the statues represented deities and allegoric personifications (Cf. Wissowa 1912: 179-180) referring on one hand to the Roman Senate and the Roman People and on the other to the Ephesian Council and Popular Assembly and to the six tribes of Ephesian citizens (IEph 27, 11. 158-219; Rogers 1991: 80-126); none of these statues have been preserved, but twelve bases furnished with inscriptions (IEph Nos. 28-36A-D) have been found in the theatre. In dealing first with the second part of the bequest (referring to the gift of statues) we take our starting-point in the following description of the procession, extracted from the main document:

The aforementioned type-statues (i.e. a copy based upon a well-known statue) should be placed during every regular assembly, and during the new moon's sacrifice of the archieratic year in the theatre by the fitting people on the nine inscribed bases in three groups over the blocks set out as the dedication on the bases and the dedication in the bequest for the boule (i.e. the council), the gerousia (i.e. the body of the elderly), the ephebia (i.e. the body of young men in military service), and (each) tribe. After the assemblies have been dismissed, the type-statues and the images should be carried back to the sanctuary of Artemis and should be handed over to the guards, two of the neopoioi and a beadle attending, to Mousaios, sacred slave of Artemis, custodian of the things deposited, the ephebes receiving and escorting from the Magnesian Gate into the theatre, and from the theatre right to the Koressian Gate in all due dignity.

3 The inscription was reproduced on 16 tablets of stone and made up in two copies; one was placed in the temple of Artemis, and the other was set up in the theatre. The inscription has been reproduced and translated into German in 'Die Inschriften von Ephesus' (= Eph), I, No. 27, pp. 167-222) An English translation facing the Greek text is given in Rogers 1991: 153-187. 
In like manner (let it) be during all athletic contests, and if any other days are determined by the boule and the demos. (IEph 27, 1l. 202-214. Transl. G. M. Rogers)

From this informative part of the text we learn about the timing of the procession, its way through the city, and the placing of the statues. It was stipulated that it should take place on the day when the high priest of the common temple of Asia in Ephesus took office, during the twelve sacred and regular assembly meetings fixed by law and custom, at the time of the Sebasteia, the Soteria, and the penteric Great Ephesia, during all gymnastic games, and on other occasions determined by the Popular Assembly and the Council; from these data we can assume that the procession would have taken place at least every two weeks in the city throughout the year (Rogers 1991: 83). At these occasions the statues were to be carried by various categories of temple servants, most likely in portable shrines (Cf. Acts 19: 24; Picard 1922: 242), from the temple to the theatre and set up on nine bases in groups of three, and afterwards they were to be carried back and replaced in the temple; most likely the carriers went on foot until the reign of Antoninus Pius (A.D. 138161), when sacred waggons began to appear on Ephesian coins (Hill 1897: 87-88). On its circular route, in all about 7 kilometres, the procession passed through two of the city gates, where the ephebes took over the escort through the city. Judging from the distance, the procession moved approximately about 90 minutes in front of the crowds (Rogers 1991: 110), and since the number of ephebes in the city came to about 250 at the time for the bequest, the procession included on its way inside the city wall at least 260 individuals, representing exclusively the male sex (Rogers 1991: $86)$.

Turning now to the consecutive order of the statues carried in the procession, we are entitled to make the following reconstruction based on the careful lines of direction given in the main document. 27 statues, arranged in nine groups by three, were carried by various groups of temple servants. The triad at the head of the procession was led by a golden statue of Artemis Ephesia with two silver stags about her, presenting her as the 'Multimammia' ('with many breasts'). This statue, well-known all over the Mediterranean area, showed the goddess as a protectress of the temple and the city of Ephesus (Oster 1990: 701). The figure was covered with various symbols of procreativity, presumably a heritage from the Anatolian mother goddess, and furnished with a mural crown (Fleischer 1973: 46-116). The statue, pictured for the first time on Ephesian coins 
after 133 B.C., was presumably a copy based on the original 'zoanon' of Artemis Ephesia, dating back to the 7th century B.C.); according to Xenophon (Anab. V, 3, 4-13) who visited Ephesus in the 5th century B.C., the idol of Artemis Ephesia was made in gold. The 'Multimammia', propagating the prosperity of the city, appeared together with allegoric personifications made in silver representing the Roman Senate and the Ephesian Council (IEph 27, 11. 158-163). Two more statues, however, representing the Emperor Trajan and the Empress Plotina, were to be included in this group after the death of Vibius Salutaris (IEph 27, 11. 150-157); we have to assume that these imperial statues were set up in his own home during his lifetime, since there was no temple dedicated to Trajan in Ephesus; the Emperor was, as far as we know, represented in Ephesus only by a colossal statue associated with a fountain. (Price 1984: 136, 255). Distinguished from this principal groupage showing Artemis Ephesia as a goddess of fertility and material culture, the following eight triads were led by silver statues picturing Artemis Ephesia, this time as a goddess of wild nature in the guise of the Greek huntress holding a torch; only one statue representing Artemis Ephesia holding a torch has hitherto been found in Ephesus. (Rogers 1991: 111). "These two aspects of Artemis Ephesia, visible in the procession, are also to be found on Ephesian coins showing on the obverse the effigy of the Greek huntress, and on the reverse that of the 'Multimammia' (Karwiese 1970: 326-328). The statues picturing the goddess in her role of huntress were combined with various allegoric personifications referring to Rome and to the city of Ephesus. Among these statues the figure of the Roman People (IEph 27, 1l. 164-167) was an important counterpart to that of the Roman Senate, forming the letters S.P.Q.R. (Senatus Populusque Romanus) a catchword of Roman power well known from inscriptions on public buildings spreading Roman propaganda all over the Empire (Hannestad 1986: 155 and $n$. 48). In the above mentioned eight groups the most important concomitants of the city goddess were, in our point of view, the statues of the Thracian king Lysimachus (IEph 27, 11. 186-188) and Augustus (IEph 27, 11. 172-176) who were both new-modellers of Ephesus; the former because he transplanted the city from the area around the temple of Artemis Ephesia to its present situation (Bürchner 1905: 2793), and the latter because of his building activity (Knibbe and Alzinger 1980: 815-818); as regards the statue of the hunting goddess related to the one

\footnotetext{
4 According to Rogers, Artemis carrying the torch dominated the procession since the torch referred to the nocturnal procession associated with the mysteries of Artemis Ephesia which were held on her birthday in a holy grove outside the city.
} 
of Augustus, we get the information that, in addition to the torch, she was also holding a sacrificial bowl. It has been suggested that the Athenian Androklos, the original founder of Ephesus, was also represented by a statue (Rogers 1991: 107), but the inscription in its present fragmented state gives no evidence of this theory.

According to a simple model of communication we have so far primarily dealt with the message mediated by the inscription. Let us now turn to the sender and to the intended audience. Focusing first on the donor, we have scant information on the life of Vibius Salutaris; he was a rich knight of Italic origin who took up residence in Ephesus after a long military and official career in the provinces, ending up as a subprocurator first of Mauretania Tingitana and then of Belgica. He was a citizen of Rome, and also of the city of Ephesus, where he was a member of the Council; furthermore, he owned large estates in the country around Ephesus (Hanslik 1958: 1982-1983; Rogers 1991: 16-19). From the inscription we can deduce that the motives of Vibius Salutaris associated with the foundation operated on two different levels. First of all, it is evident that he was in high favour with the Emperor Trajan since he had got permission to get hold of the statues of the Emperor and the Empress; according to a letter from the Emperor to Pliny the Younger we know that Trajan was generally reluctant to accept honours of this kind (Plin. epist. 10, 8: 9). Since there are no chronological clues as to the carrier of Vibius Salutaris, we have no idea of his dealings with Trajan; we can only guess that his competence in one way or an other attracted the attention of the Emperor, and that this relationship inspired Vibius Salutaris to use his fortune in accordance with Trajan's political programme; this included a great deal of political propaganda announcing the merits of the Emperor on one hand as the victorious warrior furthering the superiority of Rome, and, on the other as the thoughtful father of the empire caring for his subjects (Hannestad 1986: 146-186); to this characteristic can be added a fear of all kinds of societies, as is testified in another letter addressed to Pliny refusing him even to organize a fire-brigade:

If people assemble for a common purpose, whatever name we give them and for whatever reason, they soon turn into a political club. (Plin. epist. 10, 34. Transl. B. Radice)

Against this background it is reasonable to assume that Vibius Salutaris - acting either on his own initiative or on the recommendation of Trajan — intended to strengthen the Roman influence in the temple of Artemis 
Ephesia - a source of political unrest - and in this respect Vibius Salutaris took even a step further than Augustus. The foundation enabled him to add statues representing the Roman Senate and the Roman People to the one of the divine Emperor Augustus already present in the temple thus discreetly reminding of the sacred hierachy of the presence of Roman rule in the city. Vibius Salutaris also tried to increase Roman influence on the municipal government in making statues representing Roman rule on different levels attend the meetings of the Popular Assembly held in the theatre; this arrangement might have functioned - at least on the psychological level - as a deterrent from popular disturbance (Cf. Acts 19: 23-41). Whether Vibius Salutaris hoped for a reward of some kind from the Emperor in acknowledgement of the bequest we do not know. From the inscription we learn that Vibius Salutaris became an honorary freeman of Ephesus (IEph 27, 1. 17), and that the Popular Assembly decided to confer on him a golden wreath and to set up his statue in the temple of Artemis as well as in frequented places in the city (IEph 27, 8789). Seen in the municipal perspective, Vibius Salutaris only continued the tradition of Ephesian aristocrats, donating money for various objects to the city (Knibbe and Alzinger 1980: 778); we can be sure, however, that the generosity displayed before the eyes of the Ephesians raised the prestige of the Roman knight in an unusually high degree.

Turning now to the audience, we can state that the crowds watching at the procession created by Vibius Salutaris consisted not only of the Ephesian population. The orator Aelius Aristides (A.D. 117 - c. 177) gives the following report on Ephesus as a metropolis attracting people from all corners of the Empire:

I think that all men who live between the Pillars of Hercules and the river Phasis would rightly regard Ephesus as having a connection with them both through the accessibility of its harbors and through all its other means of reception. All men journey to it, as if to their own country, and no one is so foolish, or so flies in the face of reality, that he would not concede that the city is the common chancellery of Asia (i.e. the seat of the governor) and a refuge in time of need. $[--]$ it is everywhere capable of providing all that a city needs and of satisfying every way of life that men can live and choose to live. (Aristid. or. XXIII, 24. Transl. Ch. A. Bear)

From this evidence (corroborating the texts already quoted) we are sure to conclude that the rumour of the Salutaris procession reached far beyond the city of Ephesus, spreading around the Mediterranean the propaganda of Roman power and Ephesian prosperity. However, from the paragraph later added to the main document we can deduce that the Ephesians of 
Greek origin for several reasons received the original donation of Vibius Salutaris with mixed feelings. The Greek provenience of the city was invisible among the statues displayed in the procession: a statue of the goddess Athena was missing, although her sanctuary was the first to be erected in Ephesus (Ath. Deipn. 8. 361), and, as far as we know, also a statue of Androklos who originally founded the city. In addition, Artemis Ephesia could just as well be seen as a Roman goddess; she had a temple in Rome on the Aventine (Wissowa 1912: 332), and the attribute of a torch characterized the Roman Artemis worshipped at Nemi (Cf. n. 4. and Wissowa, 1912: 251); and, all the more, the mighty Ephesian city goddess was presented in the procession as subordinate to Rome, since she was pictured as pouring a libation to the deified Augustus. The negligence of the fact that Ephesus was originally colonized by the Athenians might have excited the Ephesian Greeks to such a degree that Vibius Salutaris extended his original donation; besides another sum of money, he added to the procession two statues on the divine level, this time made in gilded silver. One, representing the goddess Athena Pammusos, was to be carried together with a personification of Ephesian young men below the age of military service (IEph 27, ll. 465-469). The epithet of 'Pammusos', relating the goddess to the nine Muses, presented her as a patroness of all Arts underlining the Athenian origin of Ephesus as a centre of spiritual culture (Knibbe 1970: 290-293), and her relationship to young boys hinted at the future survival of this Greek heritage in the city. However, besides the statue of Athena Pammusos, Vibius Salutaris donated another one picturing the allegoric personification of Concordia Augusta Chrysophorus; this statue was apparently meant to emphasize the material benefit originating in a harmonious relationship between Rome and its subordinate cities. The message of the Concordia, spread also by the 'Multimammia', was certainly meant as a memento at first hand to the Ephesians of Greek origin not to try to rebel against Rome (Knibbe and Alzinger 1980: 752-753), since the appearance of Concordia in Rome was always connected with conflicts of various kinds asking for a peaceful solution (Wissowa 1912: 328-329); we are sure to assume, however, that the signal, announcing subordination to Roman rule, spread around the Mediterranean far beyond its intended audience. Before ending the discussion of the second part of the bequest, the purpose of the procession will be scrutinized. No religious ceremony is mentioned in connection with the parade created by Vibius Salutaris; the aim of this spectacle was obviously to demonstrate that Roman power was superior even to the mighty city goddess of Ephesus. The political stamp on the 
procession is further evident from the fact that no women participated although Artemis Ephesia was an important protectress of the female sex specifically in case of childbirth (Apul. met. XI, 2; cf. Bammer 1984: 253-254); according to the inscriptions Ephesian women took part in the affairs of the city only in the role of officially appointed priestesses donating money for the public weal (Knibbe 1981: 101-105; cf. Portefaix 1988: 50-51).

However, Vibius Salutaris intended not only to impart Roman influence on the cult of Artemis Ephesia by placing statues in her temple. According to the first part of the bequest he made her servants, besides representatives of the municipal government, dependent on Roman money by a gift which was annually distributed in the temple by the high priestess on the birthday of the goddess (IEph 27, 1. 265; Rogers 1991: 44); it is easy to believe that this gift of money furnished the receptors with a sensitive ear to Roman wants. Consequently, Roman power overshadowed the birthday of Artemis Ephesia, which used to be traditionally celebrated in the springtime by a festive procession true to the Greek origin of the city; thanks to a pictorial account in the romance Ephesiaca by Xenophon, dated to the second century A.D., we have got the only preserved description of this procession held in honour of the goddess; unfortunately, there is no local clue to the city of Ephesus in Xenophon's report (cf. Kerényi 1927: 48). According to Suidas, however, Xenophon originated from Ephesus, and, besides the romance in question, he is said to have written a (now lost) book on the city (Gärtner 1975: 1430). Therefore, we have reason to believe that the rituals, performed at the temple of Artemis Ephesia, were well known to him. Since the temple was a famous resort of pilgrims, they might also have been known to his audience, and, consequently, Xenophon's account could easily be checked. It runs as follows:

The yearly festival in honour of Artemis was held at Ephesus; her temple being scarce seven furlongs (i.e. nearly one English mile) distant from the city. The virgins of that place, in their richest attire, assisted at the celebration, as also the young men of the age of Abrocomas (i.e. the hero of the story), who was in his sixteenth year. [-- ]. A mighty concourse of people, as well strangers as citizens, were present; and then the virgins were wont to look out for spouses, and the young men for wives. The procession moved regularly along: the holy utensils, torches, baskets and perfumes, led the van in the forefront; and were followed by the horses, hounds, and hunting accoutrements, as well as for attack as for defence. Each of the virgin train behaved as in the presence of their lover. They were led by Anthia (i.e. the heroine of the story) ${ }^{5}[---]$. Her attire was

5 At this time a high priestess was at the head of the temple (IEph 27, 1. 265), and it 
a purple dress hanging down from her waist to her knees, the skin of a fawn girded it round, on which hung her quiver and arrows. She bore her hunting arrows and javelins, and her hounds followed her. The Ephesians beholding her in the grove, have often adored her as their goddess [-- ] affirming her to be Artemis herself [-- ]. When the procession was over, all the multitude entered the temple to offer sacrifice. (Xen. Ephes. I, 2. Transl. from Falkener 1862, $335-336)$

Compared with the Salutaris procession, the different character of the one described by Xenophon is obvious. In the former the goddess headed the procession which was moving in a circle with the only purpose of making propaganda of the benefits resulting from Roman supremacy; the birthday procession on the other hand was ended by the goddess herself welcoming the crowds to her temple, where the celebration culminated in a sacrifice. Besides the religious character we notice the Greek stamp on this ritual: Artemis Ephesia is represented by a young priestess in the guise of the Greek hunting goddess, and her role of huntress is further underlined by the display of various weapons needed for the chase. The girl, representing Artemis, is accompanied by a train consisting of young unmarried people of both sexes looking for a spouse. However, this role of match-maker, attributed to the Greek Artemis, does not agree with her character as a goddess of virginity (Oster 1990: 1722); this element of the story, referring to a goddess of fertility, might be either a relict from the cult of the indigenous Anatolian mother goddess originally worshipped in Ephesus (Oster 1990: 1687-1688) or a trait characteristic of the style of the hellenistic romance (Rohde 1900: 409-435).

The birthday procession, in addition to the one created by Vibius Salutaris (besides others being beyond my scope in this context), validates the suggestion that the Ephesian streets were often the scene of processions of various kinds. The idea of this ritual also found its way to the Ephesian church (Knibbe 1970: 293-294), ${ }^{6}$ being reflected in a letter written by the Bishop Ignatius from Antioch. At that time Ignatius set out for Rome, where he was going to be martyred, and on his way through Asia Minor he wrote a number of letters to the Christian communities in the area (Euseb. hist. eccl. III, 36); the letters are considered to have been written roughly between A.D. 107-110 (Vielhauer 1978: 545). We have reason

\footnotetext{
is likely that this office, involving great responsibility, was held by an elderly woman.

${ }^{6}$ Christianity secured a footing in the city in the middle of the first century A.D. The Ephesian church had a strong position based on the apostolic tradition; Paul founded the community, his companion Timothy became its first bishop, and John the Evangelist worked and died in the city, where he wrote the fourth Gospel.
} 
to believe that Ignatius was well informed about the pagan religious life in Ephesus (Cf. Ignat. epist. Magn. XV, 1; epist. Trall. XIII, 1) since he was accompanied on his journey by two deacons (Ignat. epist. Eph. II, 1), named Burrhus (Cf. Ignat. epist. Phil. XI, 2; epist. Smyrn. XII, 1) and Crocus (Cf. Ignat. epist. Rom. X, 1), at home in the Ephesian church. In the letter, addressed to the Ephesians, we can trace two indirect references to the tradition of the erection of the temple of Artemis Ephesia:

Of grandeur as conceived by the Greeks a real and remarkable example still survives, namely the Temple of Diana (i.e. the Roman name for Artemis) at Ephesus, the building of which occupied Asia Minor for 120 years. [---] The crowning marvel was his (i.e., the architect) success in lifting the architraves of this massive building into place. [-- ] the greatest difficulty was encountered with the lintel itself when he was trying to place it over the door; for it was the largest block, and it would not settle on its bed. The architect was in anguish as he debated whether suicide should be his final decision. The story goes that in the course of his reflections he became weary, and while he slept at night he saw before him the goddess for whom the temple was being built: she was urging him to live because, as she said, she herself had laid the stone. And on the next day this was seen to be the case. (Plin. nat. hist. 36, 95-97. Transl. D. E. Eichholz)

Ignatius seems to allude to this pagan tradition, preserved by the elder Pliny, in order to explain the character of Christianity as a spiritualized religion opposed to the pagan cults:

[-- ] you (i.e. Ephesian Christians) are as stones of the temple of the Father, made ready for the building of God our Father, carried up to the heights by the engine of Jesus Christ, that is the cross, and using as a rope the Holy Spirit. And your faith is your windlass [-- ]. (Ignat. epist. Eph. IX, 1. Transl. K. Lake)

In the eyes of the Ephesian Christians the tangibly presented vision of Christ himself building the Temple by means of the Cross and the Holy Spirit as his tools was suggestive of the tradition that at the erection of her temple Artemis Ephesia herself helped the architect. This passage is usually seen as influenced by Gnosticicm (Schoedel 1985: 66); in my opinion, however, the pagan tradition associated with the temple of Artemis Ephesia must also be taken into consideration as a plausible background of this text. Similar to the goddess, who rescues the life of the architect by placing the heavy stone lintel over the entrance door with her own hands, Christ rescues his followers by erecting a spiritualized Temple in their hearts. Ignatius then goes on to describe a procession made up of Ephesian Christians on their way to God: 
[-- ] and love is the road which leads up to God. You are then all fellow travellers, and carry with you God, and the Temple, and Christ, and holiness, and are in all ways adorned by commandments of Jesus Christ. (Ignat. epist. Eph. IX, 1-2. Transl. K. Lake)

The image of Ephesian Christians carrying God in a shrine alludes to the Salutaris procession (Shoedel 1985: 67; cf. Dölger 1934: 73), while the carrying of 'Christ and holiness' seemingly brings out a spirtualized application of the motive. However, the Salutaris parade contrasted with the procession of Christian pilgrims not being on their road on some special occasion to a temple made of stone but themselves being temples always carrying God and his demands in their hearts. In Ignatius' letter Vibius Salutaris' secular procession demonstrating earthly power became metaphorically transformed into a spiritualized ritual defining in moral terms Christian identity and the adherence to the Kingdom of God. Finally, Ignatius names himself Theophorus (i.e. God bearer) in the preface to all his letters; whether this was his second proper name given by birth has been much discussed among scholars (Schoedel 1985: 35-36). It cannot be excluded, however, that Theophorus only points to the fact that Ignatius regarded his journey from Antioch to Rome in the context of a procession ending up with his own death; in such a case we may imagine the Bishop of Antioch in the front of the procession described in the Ephesian letter triumphantly leading his fellow Christians on their way leading up to the Kingdom of God.

To conclude: in the beginning of the second century A.D. the public religious life in the city of Ephesus was to a great extent characterized by processions relating to the cult of Artemis Ephesia. The one traditionally performed on the birthday of the goddess called to mind the Greek origin of the city; it was strictly associated with the religious sphere bringing about a close relationship between the goddess and her adherents. The other, artificially created by a Roman, was entirely secular, and spread its message every fortnight in the streets of Ephesus. It referred to the political field of action and intended to strengthen the Roman rule over the city on two levels. The presence of statues, representing Roman instruments of power, in the temple of Artemis Ephesia elevated Roman rule into the domain of the gods, and the placing of these statues in the theatre made the presence of Roman power tangibly conscious to the members of the Popular Assembly, reminding them of their position as citizens of a city subordinate to Rome. The tension between Roman rule and Greek spritual culture became clear in the Salutaris bequest; the 
Greek origin of Ephesian culture was later included in the message of the procession by a statue portraying the Athenian city goddess, and at the same time a statue of Concordia was added reminding the Greeks not to rebel against Roman rule. This secular parade, conceptualizing Roman power and Greek cultural identity, found its way even to the Ephesian church. It was metaphorically used by a Christian Bishop making propaganda for the Kingdom of God in explaining the character of spiritualized Christian worship showing itself exclusively in the observance of the Commandments.

\section{References Cited}

\section{Inscriptions}

Die Inschriften von Ephesos (IEph)

1979 Die Inschriften von Ephesos; Teil Ia. Hrsg. von H. Wankel. Bonn: Rudolph Habelt Verlag. (Inchriften Griechischer Städte aus Kleinasien, 11/1)

\section{Texts and translations}

The Apostolic Fathers

1976-77 The Apostolic Fathers; vol. 1. Transl. by Kirsopp Lake. Cambridge, MA: Harvard University Press. (Loeb Classical Library, 24)

Apuleius (Apul. met)

1977 The Golden Ass being the Metamorphoses of Lucius Apulesus. Transl. by W. Adlington. Cambridge, MA: Harvard University Press. (Loeb Classical Library, 44).

P. Aelius Aristides (Aristid, or.)

1986 The Complete Works; vol. I: Orations. Transl. by Ch. A. Behr. Leiden: E. J. Brill.

Athenaeus (Ath. Deipn.)

1959-69 The Deipnosophists; vol. IV: Books VIII-X. Transl. by C. B. Gulich. Cambridge, MA: Harvard University Press. (Loeb Classical Library, 235)

Dio Crysostom (Dio Chr. or)

1946-71 Dio Crysostom; vol. III: Discourses XXXI-XXXVI. Transl. by J. W. Cohoon and H. Lamar Crosby. Cambridge, MA: Harvard University Press. (Loeb Classical Library, 358)

Eusebius (Euseb. hist. eccl)

1980 Ecclesiastical History; vol. I. Books I-V. Transl. by Kirsopp Lake. Cambridge, MA: Harvard University Press. (Loeb Classical Library, 153)

The Greek Anthology (Anth. Gr.)

1970-83 The Greek Anthology; vol. III. Transl. by W. R. Paton. Cambridge, MA: Harvard University Press. (Loeb Classical Library, 84)

Ignatius (Ignat. epist.)

See Apostolic Fathers 
Pausanias (Paus.)

1966-75 Description of Greece; vol. II: Books III-V. Transl. by W. H. S. Jones and H. A. Ormerod. Cambridge, MA: Harvard University Press. (Loeb Classical Library, 188)

Pliny the Elder (Plin. nat. hist.)

1966-79 Natural History; vol. X. Transl. by D. E. Eichholz. Cambridge, MA: Harvard University Press. (Loeb Classical Library, 419)

Pliny the Younger (Plin. ep.)

1972-76 Letters and Panegyricus; vol. II. Transl. by Betty Radice. Cambridge, MA: Harvard University Press. (Loeb Classical Library, 59)

Xenophon (Xen. Anab.)

1961-84 Anabasis; vol. III (I-VII). Transl. by Carleton L. Brownson. Cambridge, MA: Harvard University Press. (Loeb Classical Library, 90)

Xénophon d' Éphèse (Xen. Ephes.)

1926 Les Éphésiaques. Text établi et traduit par Georges Dalmeyda. Paris: Société d' édition "Les Belles Lettres".

\section{Literature}

\section{Bammer, Anton}

1984 Das Heiligtum der Artemis von Ephesos. Graz: Akademische Druck- u. Verlagsanstalt.

\section{Bürchner, Ludwig}

1905 Ephesos. In: Pauly's Real-Encyclopädie der classischen Altertumswissenschaft; vol. 5 ; cols. 2773-2822. Stuttgart: J. B. Metzler Buchhandlung.

\section{Bömer, Franz}

1952 Pompa. In: Pauly's Real-Encyclopädie der classischen Altertumswissenschaft; suppl. 21/2; cols. 1878-1994. Stuttgart: Alfred Druckmüller Verlag.

Dölger, Franz Joseph

1934 Christophorus als Ehrentitel für Martyrer und Heilige im christlichen Altertum. In: Antike und Christentum; vol. 4; pp. 73-80. Münster: Aschendorffsche Buchhandlung.

Fleischer, Robert

1973 Artemis von Ephesos und Verwandte Kultstatuen aus Anatolien und Syrien. Leiden: E. J. Brill.

\section{Gärtner, Hans}

1975 Xenophon von Ephesos; (7). In: Der kleine Pauly. Lexikon der Antike; vol. 5; col. 1430. München: Alfred Druckenmüller Verlag.

Hannestad, Niels

1986 Roman Art and Imperial Policy. In: Jutland Archaeological Society Publications 19; pp. 143-186. Aarhus: Aarhus University Press.

Hanslik, Rudolph

1958 Vibius Salutaris; (5). In: Pauly's Real-Encyclopädie der classischen Altertumswissenschaft; vol. 12/A/2; cols. 1982-1983. München: Alfred Druckmüller Verlag.

Hill, George Francis

1897 Notes on Additions to the Greek Coins in the British Museum 1887-1896. The Journal of Hellenic Studies 17: 87-88. 


\section{Karwiese, Stefan}

1970 Ephesos C. In: Pauly's Real-Encyclopädie der classischen Altertumswissenschaft; suppl. 12; cols. 297-364. Stuttgart: Alfred Druckmüller Verlag.

Kerényi, Karl

1927 Die Griechisch-Orientalische Romanliteratur in religionsgeschichtlicher Beleuchtung. Tübingen: J. C. B. Mohr (Paul Siebeck).

\section{Knibbe, Dieter}

1970 Ephesos A. In: Pauly's Real-Encyclopädie der classischen Altertumswissenschaft; suppl. 12; cols. 248-297. Stuttgart: Alfred Druckmüller Verlag.

1981 Der Statsmarkt. Die Inschriften des Prytaneions. Kureteninschriften und sonstige religiöse Texten. Wien: Österreichisches Archäologisches Institut. (Forschungen in Ephesos, 9/1/1)

Knibbe, Dieter, and Wilhelm Alzinger

1980 Ephesos vom Beginn der römischen Herrschaft in Kleinasien bis zum Ende der Pincipatzeit. In: Aufstieg und Niedergang der Römischen Welt 2/7/2; pp. 748-830. Berlin: Walter de Gruyter.

Nilsson, Martin P:n

1916 Die Prozessionstypen in griechischer Kult. Jahrbuch des Kaiserlich Deutschen Archäologischen Instituts 12/4/3: 309-339.

Oster, Richard E.

1990 Ephesus as a Religious Center under the Principate; vol. 1: Paganism before Constanine. In: Aufstieg und Niedergang der Römischen Welt 2/18/3; pp. 1661-1728. Berlin: Walter de Gruyter.

Picard, Charles

1922 Éphèse et Claros. Recherches sur les sanctuaires et les cultes de L'Ionie du Nord. Paris: E. de Boccard.

Portefaix, Lilian

1988 Sisters Rejoice. Paul's Letter to the Philippians and Luke-Acts as Seen by First-century Philippian women. Stockholm: Almqvist \& Wiksell International. (Coniectanea Biblica. New Testament Series, 20)

Price, S. R. F.

1984 Rituals and Power. The Roman imperial cult in Asia Minor. Cambridge: Cambridge University Press.

\section{Rogers, Guy MacLean}

1991 The Sacred Identity of Ephesos. Foundation Myths of a Roman City. London: Routledge.

Rohde, Erwin

1900 Der griechische Roman und seine Vorläufer. 2. Auf. Leipzig: Breitkopf und Härtel.

Schoedel, William $\mathbb{R}$.

1985 Ignatius of Antioch. A Commentary on the Letters of Ignatius of Antioch. Philadelphia: Fortress Press. (Hermeneia. A Critical and Historical Commentary on the Bible)

Vielhauer, Philipp.

1978 Geschichte der urchristlichen Literatur. Berlin: Walter de Gruyter.

Wissowa, Georg.

1912 Religion und Kultur der Römer. 2. Aufl. München: Verlag C. H. Beck. 